\title{
A Comparative Study of Different Multilevel Converter Topologies for High Power Photovoltaic Applications
}

\author{
Priyanka A. Bettawar \\ PG Scholar, Department of Electrical Engineering \\ Shri Sai College of Engineering \& Technology \\ Bhadrawati, Maharashtra, India.
}

\author{
Sumit R. Punam \\ Assistant Professor, Department of Electrical Engineering \\ Shri Sai College of Engineering \& Technology \\ Bhadrawati, Maharashtra, India.
}

\begin{abstract}
The main goal of this paper is to develop a multilevel converter topology to be useful in photovoltaic system applications. Although many topologies are introduced rapidly using a bunch of switches and isolated dc sources, having a single-dc-source multilevel inverter is still a matter of controversy. In fact, each isolated dc source means a bulky transformer and a rectifier that have their own losses and costs forcing the industries to avoid entering in this topic conveniently. On the other hand, multilevel inverters topologies with single-dc-source require associated controllers to regulate the dc capacitors voltages in order to have multilevel voltage waveform at the output. Thus, a complex controller wouldn't interest investors properly. Consequently, developing a singledc-source multilevel inverter topology along with a light and reliable voltage control is still a challenging topic to replace the 2-level inverters in the market effectively.

This work investigates modern topology of multilevel converters, which are suitable to be used in high power photovoltaic applications with the main target on achieving lower total harmonic distortion and better efficiency. Multilevel converters offer several advantages compared to conventional types. Multilevel converters provide high quality output while using the low switching frequency. It affects the switching losses, size of semiconductor switches and harmonic filters. This research investigates various topologies of multilevel converter for high power photovoltaic applications. All topologies are simulated using MATLAB/SIMULINK in the same operating conditions. Finally, the more suitable multilevel topology is chosen with reference to the simulation results.
\end{abstract}

Keywords- Cascaded Inverters, Flying Capacitor, Grid connected Multi-level inverters (GCMLIs), Hybrid Inverter, Multilevel inverter (MLI), Solar Photovoltaic (PV).

\section{INTRODUCTION}

The continuous growth of the electrical power system, resulting in an increase of electric power demand across the globe forces us to switch to other sources of energy. Renewable Energy sources are most popular among other sources because of their less carbon emission which plays a major role in reducing Global warming. As the efficiency of Renewable energy sources is relatively less than that of conventional fossil fuels, so improvements are made on either side for the purpose of power quality improvement as well increase the usage of Renewable Energy sources. In the supply side Maximum Power Point tracking is implicit whereas within the converter side the reduction of Total Harmonic distortion as well the increase of the output levels of
Multilevel Inverter is one to increase the performance of Renewable Energy Sources.

\section{MULTILEVEL INVERTER TOPLOGIES}

Because of reduced disturbances and operational losses at lower switching frequency makes the Multilevel Inverter more appropriate for Renewable Energy sources. Multilevel Inverters gives smoother output waveforms once the levels are increased at the same time the Total Harmonic distortion in additionally reduced [2], [14]. The numbers of levels are inversely proportional to Total Harmonic Distortion such that THD becomes zero at infinity levels. Increasing the levels increases the component necessity and control complexity, so the selection of appropriate topology is necessary to overcome the above disadvantages [4]. The usually used multilevel inverter topologies are Diode Clamped multilevel inverter (DCMLI), Flying Capacitor Multilevel Inverter (FCMLI), and Cascaded Multilevel Inverter (CMLI).

\section{A. Diode Clamped Multilevel Inverter}

The Neutral point Clamped MLI (NPCMLI), also known as a Diode Clamped MLI (DCMLI) [17] was first introduced by Baker and Bannister in the year 1980. Diode Clamped or Neutral Point Clamped MLI has diode that clamps the supply DC voltage to attain steps within the output wave form [6]. In DCMLI to attained $\mathrm{N}$ levels $2(\mathrm{~N}-1)$ switches, $(\mathrm{N}-1) *(\mathrm{~N}-2)$ Diodes for Clamping and (N-1) capacitors for DC link are required. The structure of a 3 phase DCMLI in fig 1 . The source Vdc is split into different voltage levels by using capacitor C1-C2 connecting them in series. The semiconductor switches Sa1 and S'a1 should allow the entire DC voltage from capacitors when switched on using PWM pulse respectively, but the diode D1-D2 should block different voltage levels such that D1 should block 3 levels decreasing down so that $\mathrm{D} 4$ should block 1 level so the step waveform is achieved in the output.

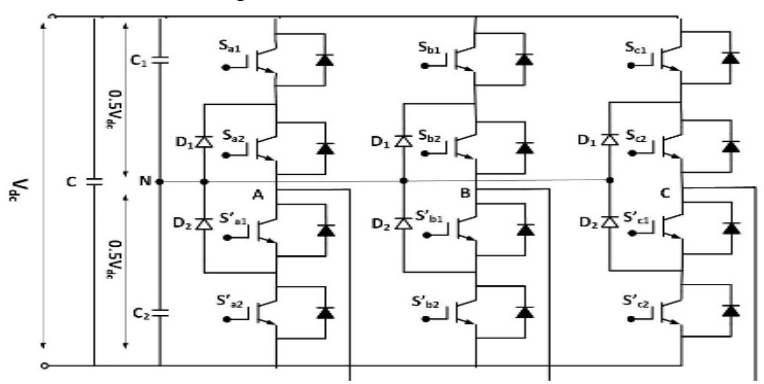

Fig.1. Three Phase diode clamped inverter. 


\section{B. Capacitor Clamped Multilevel Inverter}

The Flying Capacitor MLI (FCMLI), also known as Clamping Capacitor MLI (CCMLI), was first introduced by Menard and Foch in the year 1992 [18]. FCMLI resembles similar structure of DCMLI where the capacitors replaces the diodes [3]. Here the determination of voltage levels is done by the charging and discharging of the flying capacitors connected to the neutral point [11], [12]. Switching ON semiconductor switches S1 and S2 charges the flying capacitor CF link when the switches are turned OFF the capacitor starts discharging. The variable discharging time of every clamping capacitor creates a Multilevel within the output voltage. For obtaining $\mathrm{N}$ levels $((\mathrm{N}-1) *(\mathrm{~N}-2)) / 2$ clamping capacitors are needed. Similar to diode clamped (N1) capacitors of same rating are needed.

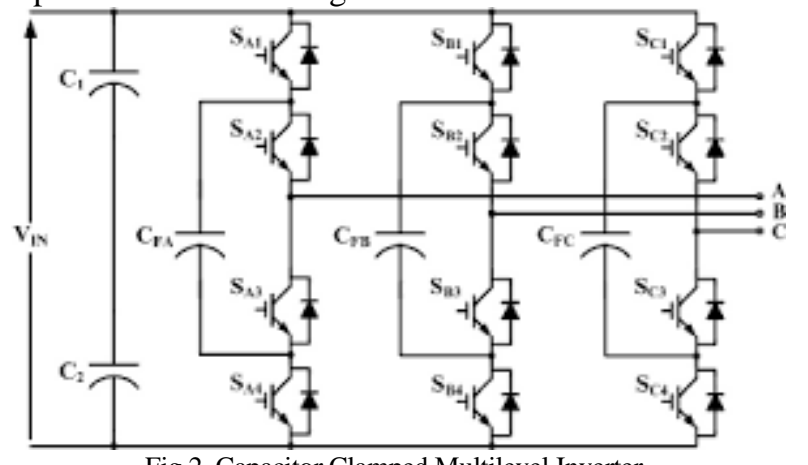

Fig.2. Capacitor Clamped Multilevel Inverter.

\section{Cascaded Multilevel Inverter}

A Cascaded Multilevel Inverter or H-Bridge Multilevel Inverter topology is that the simplest topology of Multilevel Inverter. For $\mathrm{N}$ levels $(\mathrm{N}-1) / 2$ sources are required. Each supply is connected by an H-bridge containing four semiconductor switches [9]. The H-Bridges are connected in series or cascaded manner together such that the output is taken from the top leg of the first bridge and bottom leg of the last bridge. The switching cycle of of every bridge is such how a way that 1st Bridge is ON so Vdc from the source 1 produces a level again when 2 nd bridge is $\mathrm{ON}$ the bridges 1 and 2 are cascaded therefore total of the two sources offers another level within the output is obtained. Finally when $\mathrm{N}$ bridges is ON the sum of the all the sources gives the maximum output voltage with $\mathrm{N}$-level.

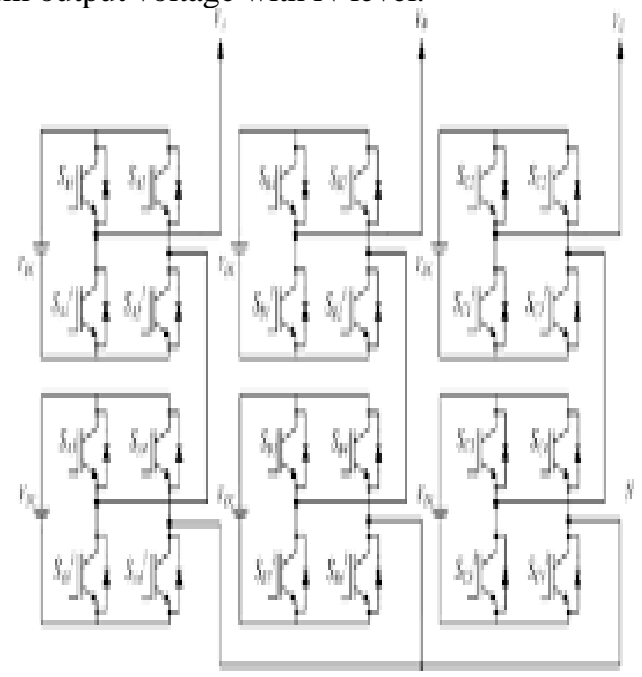

Fig.3. Cascaded Multilevel Inverter.

\section{Z-source Multilevel Inverter}

The impedance source or Z-source inverter was proposed for the first time by [19] and is shown in Fig.4. Z-source inverters distinguished it selves from other conventional types of inverters by providing voltage boost capability in common inverters. Due to generating the output voltage lower than the DC input voltage the conventional inverters are invariably a buck converter [20]. In addition the DC source will shortcircuit, if the upper and lower power switch conducts all together. Therefore, a dead band is provided purposefully between the switching on and off of the complimentary power switches of the identical leg, consequently some distortions in the output current are caused by this dead band. These drawbacks are overcome in the Z-source inverter [20]. Comprehensive discussion on the $\mathrm{Z}$-source inverter is given in $[21,22,23]$.

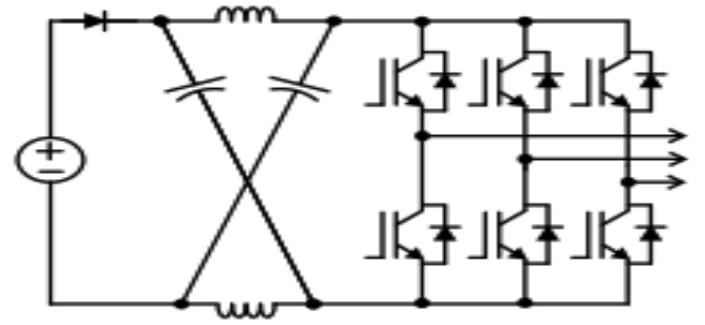

Fig.4. Z-source Multilevel Inverter.

\section{E. Quasi Z-source Multilevel Inverter}

Fig.5 presents the QZSI topology which was proposed in [16] as a derivative of the original Z-source inverter; so it contains all the benefits of the ZSI. The impedance source or $\mathrm{Z}$-source inverter has the weakness of higher stress on power switches, high voltages across the capacitors and discontinuous input (DC) current throughout boost mode [20, 22].These limitations are overcome by QZSI [22,23]. Drawing continuous current from DC supply, decreasing the voltage across the capacitor $\mathrm{C} 2$, lower elements count and therefore high reliability as well as putting lower voltage stress on the power switches are considered as the major advantages of a QZSI [20].

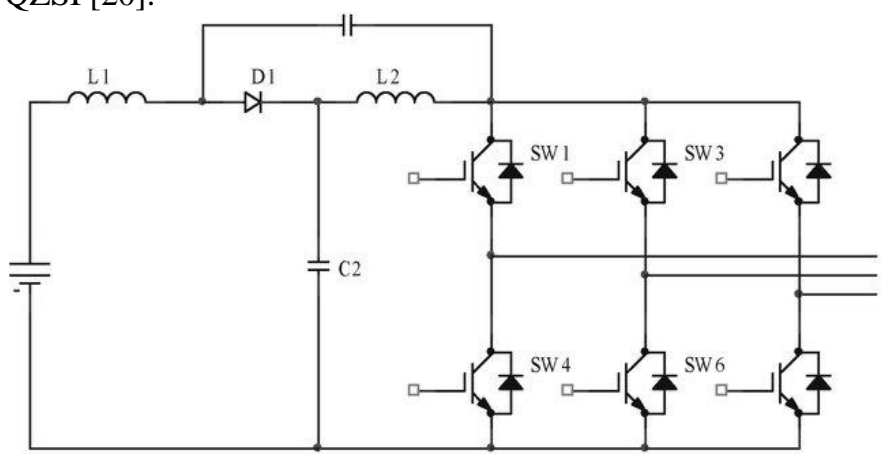

Fig.5. QZSI Multilevel Inverter.

III. SIMULATION RESULT

In this section, the most common topologies of multilevel converters, which are connected to PV array, are scrutinized in six case studies. By comparing their output wave forms and their characteristics, the most suitable inverter configuration is found. All scenarios have been done in identical situations using the same PV array source and loads while all switches are modeled as IGBT ones. The PV array module is called Canadian solar load CS5C90M with 40 parallel strings and 10 
series connected modules per strings, with irradiation of rate 1000 , temperature of $25^{\circ} \mathrm{c}$ and a three phase resistive load of $\mathrm{R}=10 \Omega$.

\section{A. Three level NPC PV source inverter}

Fig.6 illustrates a three level NPC PV source inverter model in MATLAB. The inverter is connected to the predefined PV array and load. The voltage and current wave forms of this simulation are shown in fig.7 power system is simulated in Matlab/Simulink power system toolbox software.

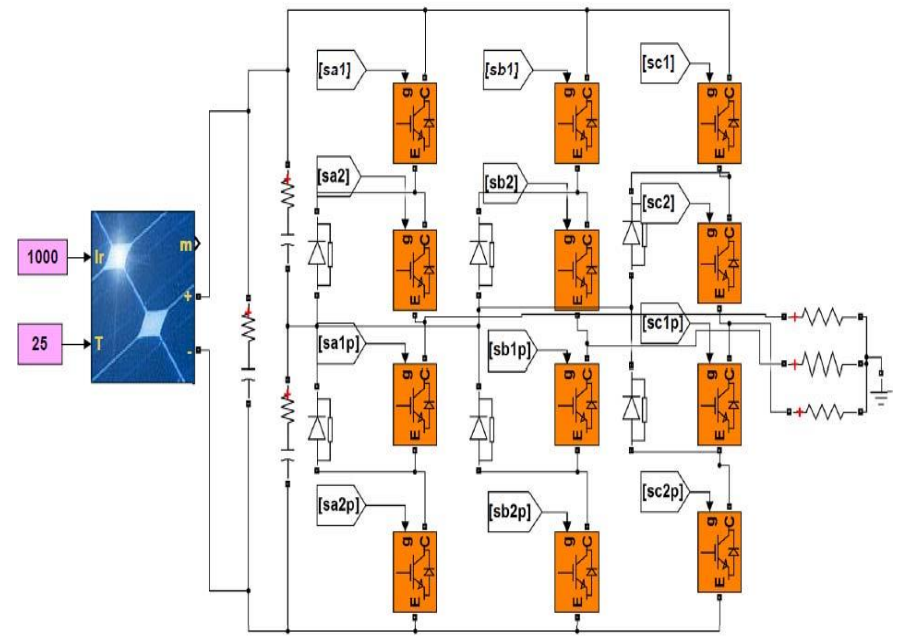

Fig. 6. Three level NPC, PV source model in Matlab/Simulink.
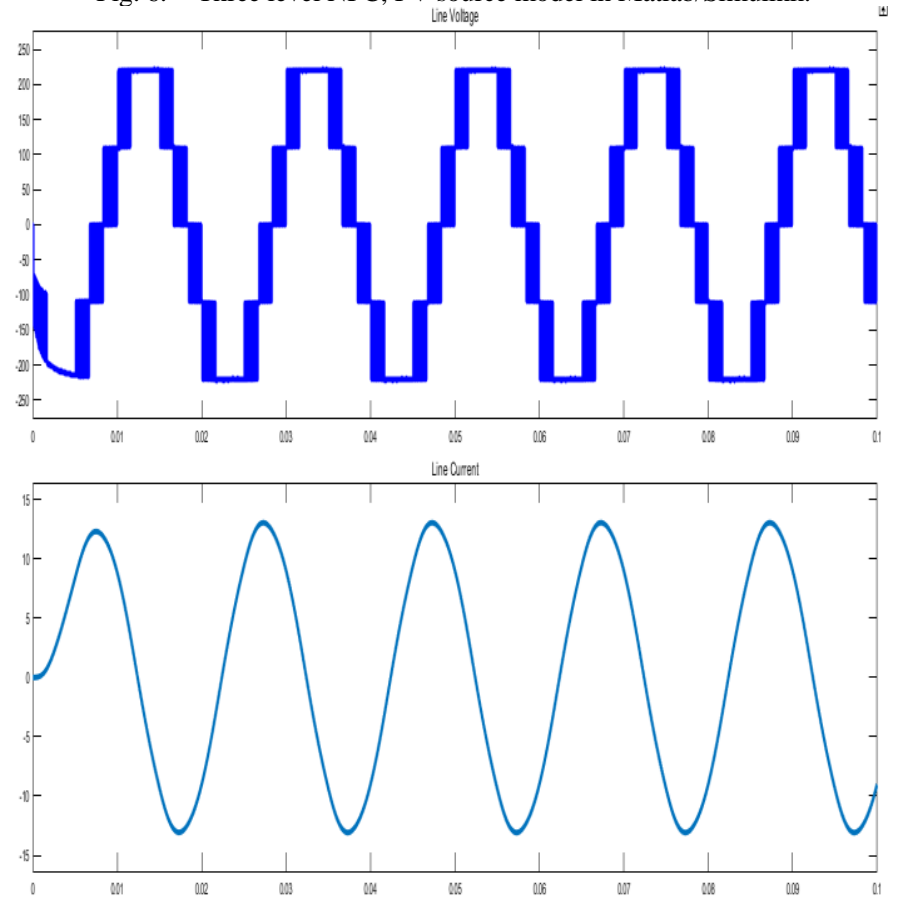

Fig. 7. Three level NPC inverter voltage and current waveforms.

The total harmonic distortion (THD) value of each waveform is calculated by Matlab/Simulink. In this way the capacitor values are considered $2200 \mathrm{~F}$ while THD of line voltage is $32.59 \%$ for this case study.

\section{B. Capacitor clamped three level PV source inverter}

Three level capacitor clamped PV source inverter model is shown in fig. 8 Capacitor values are 1000F. The voltage and current waveforms of this simulation are shown in fig. 9 THD line voltage is $44.85 \%$ for this inverter topology.

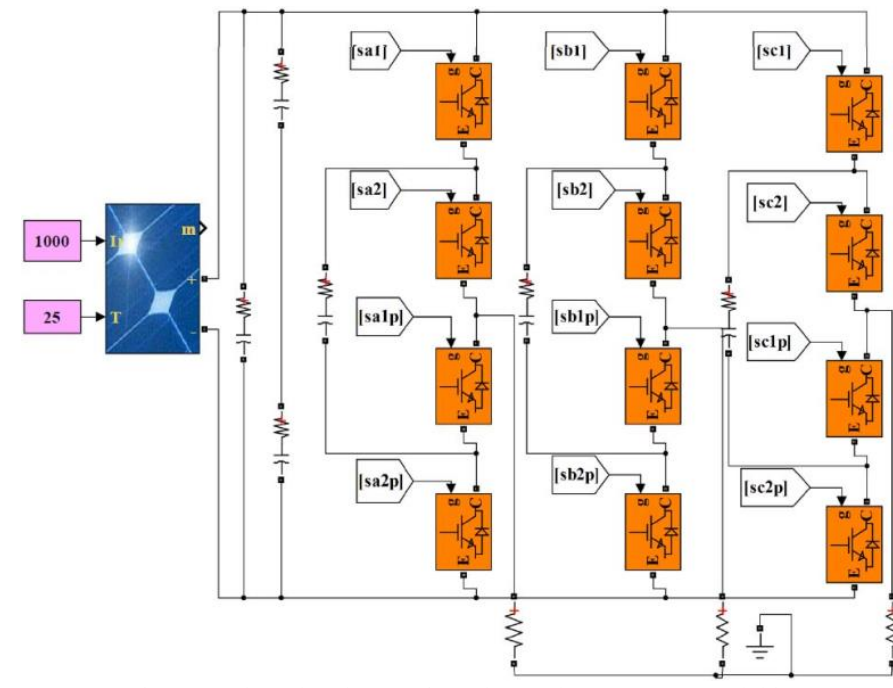

Fig. 8. Three level Capacitor clamped, PV source model in Matlab/Simulink. Fig. 9.
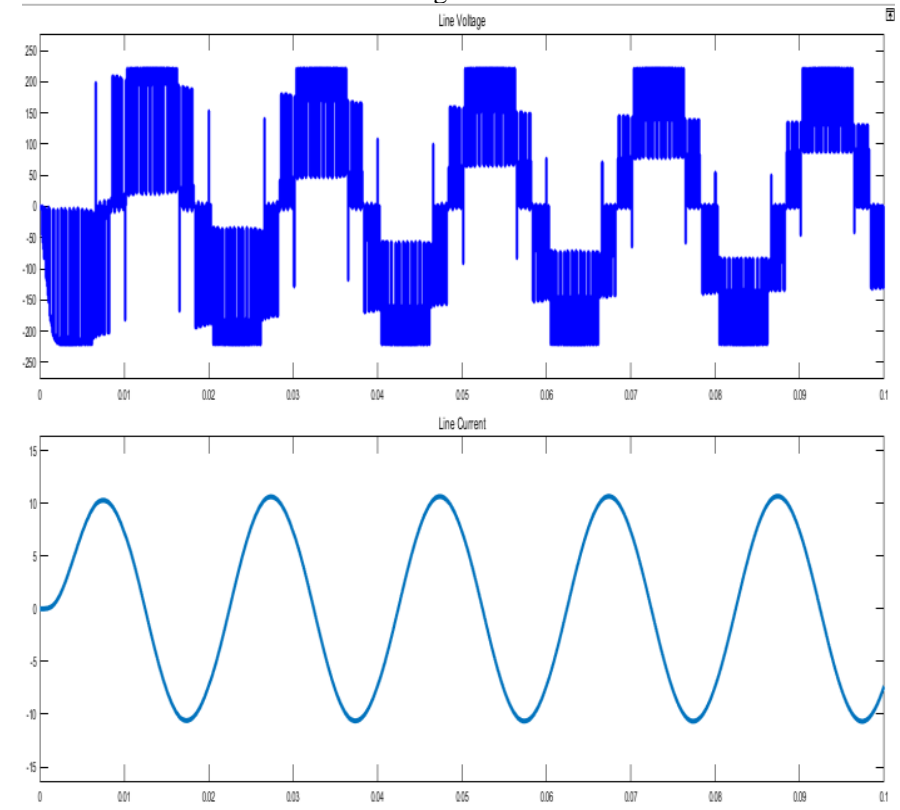

Fig. 10. Three level Capacitor clamped, PV source model in Matlab/Simulink.

\section{Three level Cascaded PV source inverter}

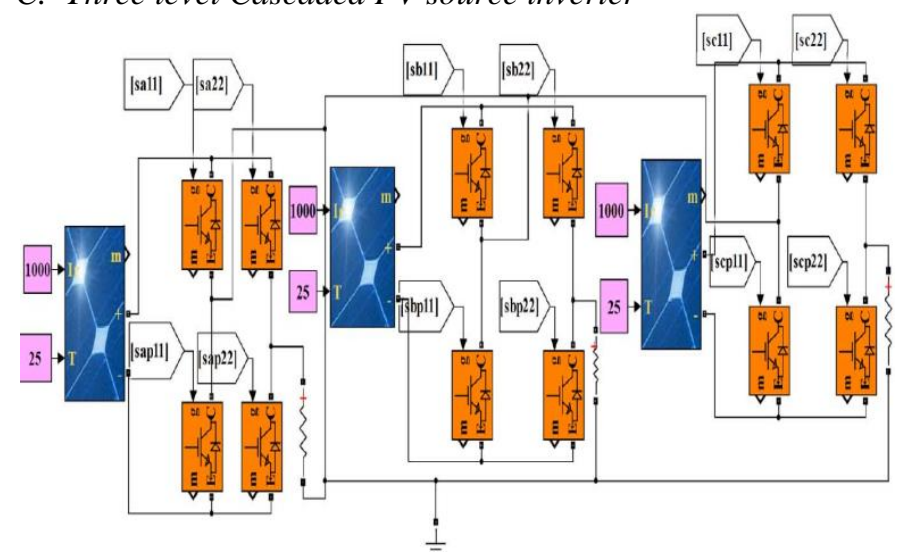

Fig. 11. Three level Cascaded $\overline{\mathrm{P} V}$ source model in matlab/simulink.

Fig.10 represents a three level cascaded PV source inverter model in MATLAB, and its voltage and current waveforms 
are depicted in fig. 11 THD line voltage is obtained $47.10 \%$ for this model.
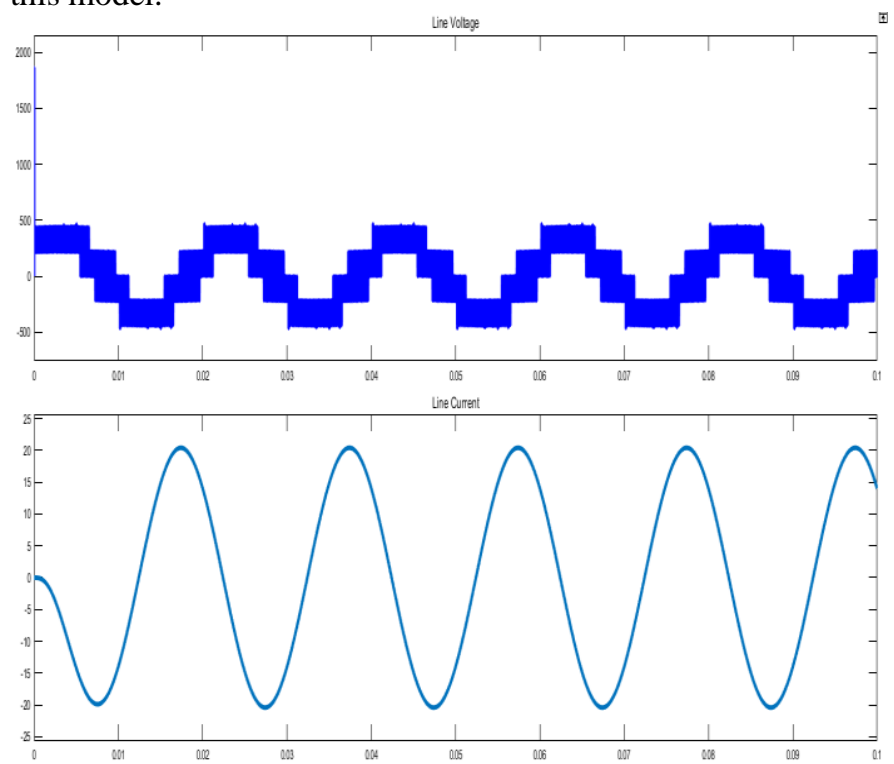

Fig. 12. Voltage and current waveforms of three level cascaded inverter.

\section{Three level Z-source PV connected inverter}

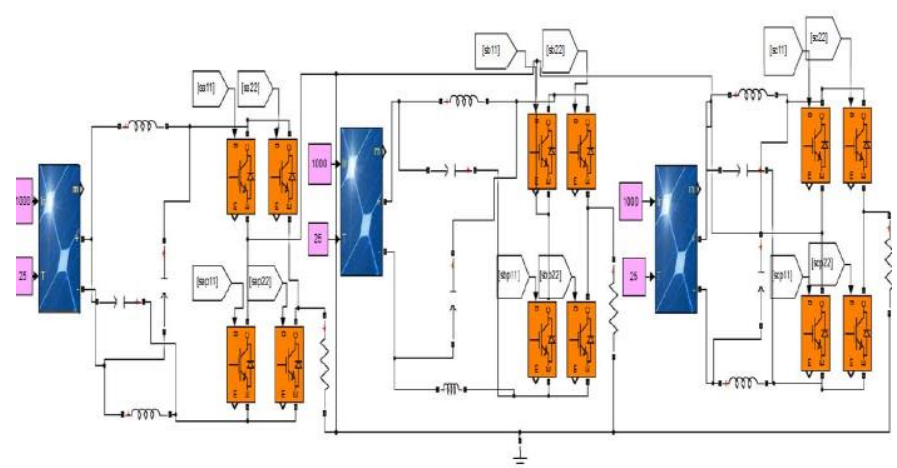

Fig. 13. Voltage and current waveforms of three level cascaded inverter. Fig. 14.
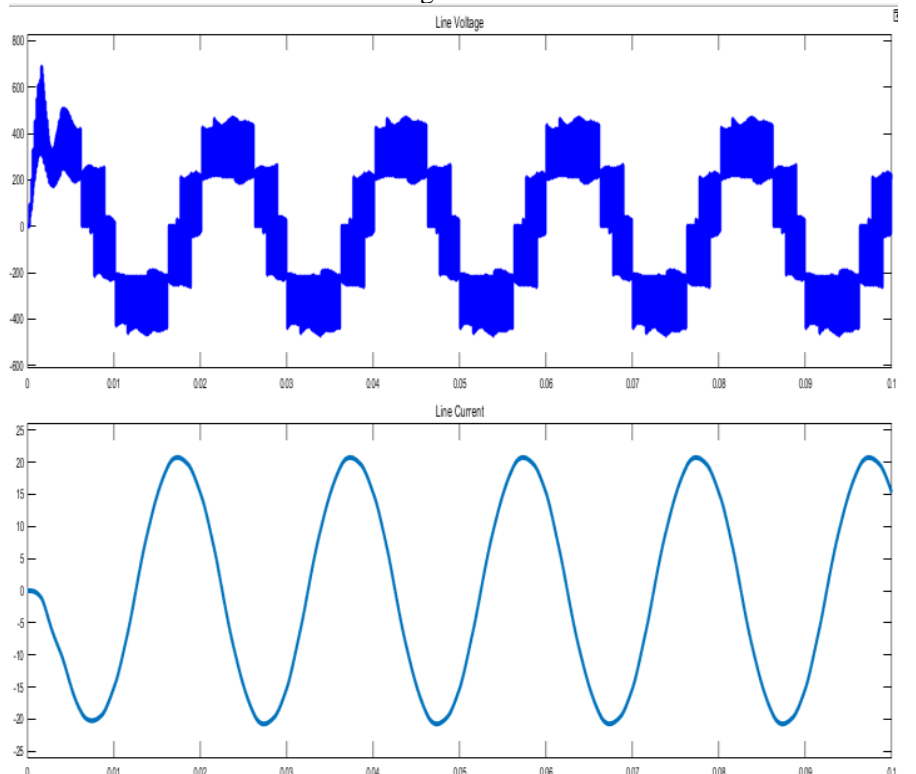

Fig. 15. Three level Z-source PV connected inverter in matlab/simulink.

Three level Z-source PV connected inverter as well as its output wave forms are shown in fig.12 and 13. The inductance values are assumed to be the same equal to $0.5 \mathrm{mH}$ as are the capacitor values $0.4 \mathrm{mF}$. THD of this modeled is measured $42.86 \%$.

\section{E. Three level Quasi-Z source PV source inverter}

The Quasi-Z source model is done according to Fig.14, and its output waveforms are shown in Fig.15. The inductance values are assumed to be the same equal to $0.5 \mathrm{mH}$ as are the capacitor values $0.4 \mathrm{mF}$. Line voltage THD for this model is $41.70 \%$.

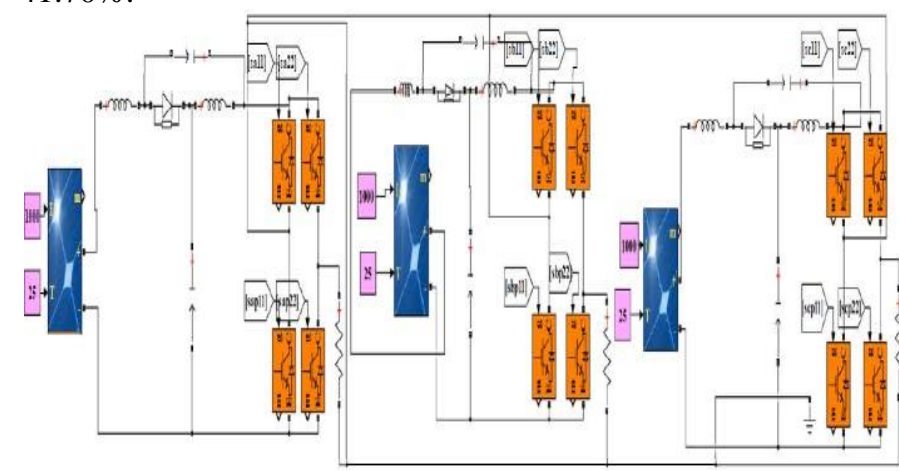

Fig. 16. Three level Quasi Z source PV connected model in matlab/simulink.

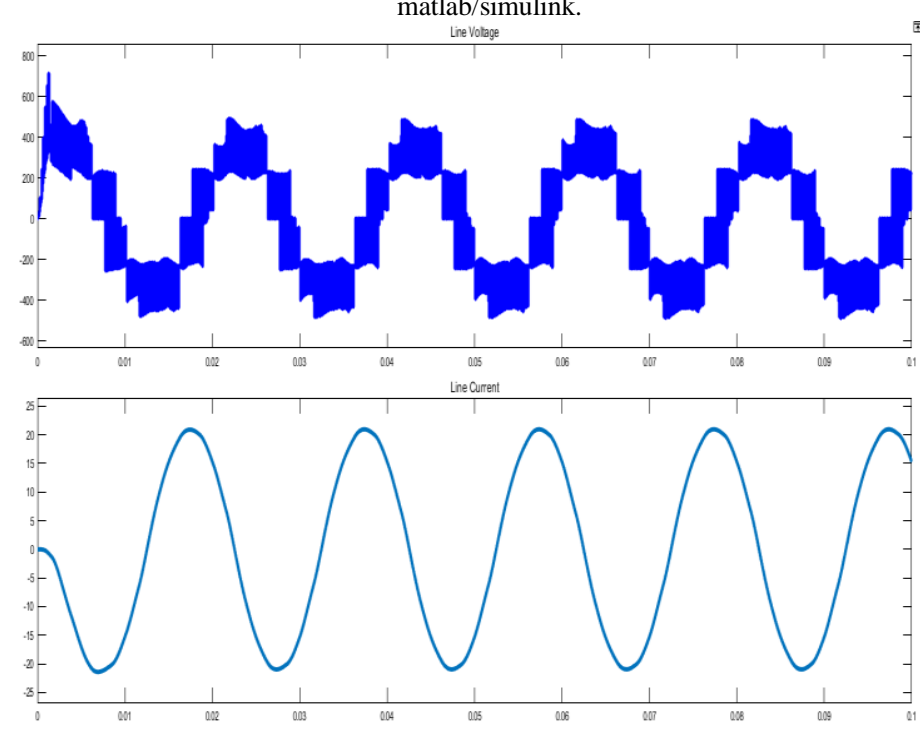

Fig. 17. Voltage and current waveforms of three level Quasi Z source.

F. Y-Connected three level Hybrid Cascaded PV source inverter



Fig. 18. Three level Hybrid PV source inverter in matlab/simulink.

Three level hybrid cascaded NPC PV source inverter model as well as its voltage and current waveforms are shown in fig.16 and 17, respectively. Capacitors values are 2200F 
while THD is $51.42 \%$. Normally hybrid topologies are used for creating high level output voltage. This concept was introduced in [19] by presenting 17-level CMI as the most suited for application to PV power generation. The simulation result of this topology confirms the low THD rate of this topology.

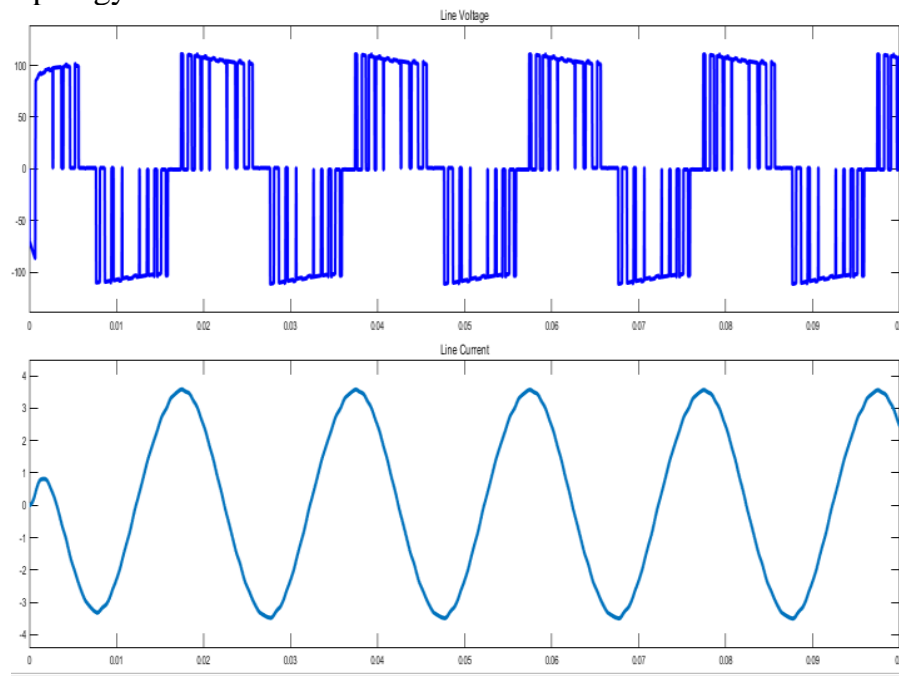

Fig. 19. Voltage and current waveforms of three level hybrid model

As it can be seen, a lot of clamping diodes in NPC topology make it very expensive and raise different issues in high voltage level applications, Therefore, the practical uses of diode clamped multilevel inverters are limited to lower than five levels [18].

The second inverter, which has a quite similar topology to the first one is the capacitor clamped topology. The major dissimilarity is the use of clamping capacitors in place of clamping diodes, and the number of switching combinations rises as capacitors do not block reverse voltages $[17,18]$. Both NPC and capacitor clamped topologies are single input inverters, however other types of topologies are modular so they reaches the higher reliability in comparison with NPC and capacitor clamped because of its modular topology [9].

Quasi-Z source inverter is introduced as a derivative of $\mathrm{Z}$ source inverter by having the ability of solving some Z-Source topology problems such as high voltages across the capacitors, and higher stress on power switches [18] and therefore reaching a reduced value of THD. In addition the efficiency of $\mathrm{Z}$ source as well as Quasi-Z source inverters are superior among other types of multi-level inverters. Hybrid multi level inverter is also considered as a suitable case in THD rate; however, its efficiency is lower than $\mathrm{Z}$ types.

\section{CONCLUSION}

The price analysis of the converter shows that multilevel converters are more economic than conventional types in the case of medium and high power applications. In This research, different multilevel converter topologies have been investigated and compared in order to find the most suitable topology, which is appropriate to use in the PV applications. Six multilevel topologies, which were proposed in the literature, have been investigated. In quantitative study, important output parameters of proposed multilevel topologies were evaluated using Matlab/Simulink at the same operating point. Also, a qualitative analysis has been performed to investigate some advantages and disadvantages of each topology, which cannot be considered in the simulation. The results prove that quasi $\mathrm{Z}$-source converter has better performance in comparison with other types.

\section{REFERENCES}

[1] McMurray (1971). Principles of inverter circuits.

[2] Nabae, A., I. Takahashi et H. Akagi. 1981. "A new neutral-pointclamped PWM inverter" IEEE Trans. Ind. Applications, no 5, p. 518523.

[3] Wu, B. 2006. High-power converters and AC drives. Wiley-IEEE Press.

[4] Steimer, P.K., H.E. Gruning, J. Werninger, E. Carroll, S. Klaka et S Linder. 1997. "IGCT-a new emerging technology for high power, low cost inverters", In Industry Applications Conference, 1997. ThirtySecond IAS Annual Meeting, IAS'97. Conference Record of the 1997 IEEE. Vol. 2, p. 1592-1599. IEEE.

[5] Kouro, S., M. Malinowski, K. Gopakumar, J. Pou, L.G. Franquelo, B Wu, J. Rodriguez, M.A. Perez et J.I. Leon. 2010, "Recent advances and industrial applications of multilevel converters",. IEEE Trans. Ind Electron., vol. 57, n 8, p. 2553-2580.

[6] Malinowski, M., K. Gopakumar, J. Rodriguez et M.A. Perez. 2010, “A survey on cascaded multilevel inverters", IEEE Trans. Ind. Electron., vol. 57, n7, p. 2197-2206.

[7] Lewicki, A., Z. Krzeminski et H. Abu-Rub. 2011, "Space-Vector Pulse width Modulation for Three-Level NPC Converter with the Neutral Point Voltage Control”, IEEE Trans. Ind. Electron., vol. 58, n 11, p. 5076-5086.

[8] Escalante, M.F., J.C. Vannier et A. Arzandé. 2002, "Flying capacitor multilevel inverters and DTC motor drive applications", IEEE Trans. Ind. Electron., vol. 49, n 4, p. 809815.

[9] Kouro, S., M. Malinowski, K. Gopakumar, J. Pou, L.G. Franquelo, B. Wu, J. Rodriguez, M.A. Perez et J.I. Leon. 2010, "Recent advances and industrial applications of multilevel converters", IEEE Trans. Ind. Electron., vol. 57, n 8, p. 2553-2580

[10] Jiyong Li and Honghua Wang, "A Novel Stand-alone PV generation System based on Variable Step Size INC MPPT and SVPWM control," Power Electronics and Motion Control Conference, 2009. IPEMC '09. IEEE 6th International, July 2009, pp. 2155 - 2160

[11] Zeng, Q., Chang L. and Song, P., "SVPWM-based Current controller with Grid Harmonic Compensation for three-phase grid connected VSI," Power Electronics Specialists Conference, 2004. PESC 04. 2004 IEEE 35th Annual, vol. 4, April 2005 pp. 2494 - 2500.

[12] Villalva, M.G., Gazoli, J.R. and Filho, E.R.; "Modeling and circuitbased simulation of photovoltaic arrays," Power Electronics Conference, IEEE 2009. COBEP '09. Brazilian, December 2009, pp. $1244-1254$.

[13] Zhou Dejia, Zhao Zhengming, Eltawil, M. and Yuan Liqiang; "Design and control of a Three-phase Grid connected Photovoltaic system with developed Maximum power point tracking,"Applied Power Electronics Conference and Exposition, 2008. APEC 2008. Twenty-Third Annual IEEE, May 2008, pp. 973 - 979.

[14] Zhou Xuesong,Song Daichun, Ma Youjie and Cheng Deshu, "Gridconnected control and simulation of single-phase two-level photovoltaic power generation system based on repetitive control," Measuring Technology and Mechatronics Automation (ICMTMA), 2010 International Conference, vol. 2, May 2010, pp. 366 - 369.

[15] Liang Ma, Wang Ran and Zheng, T.Q., "Modeling and Control of 100 $\mathrm{kW}$ Three-phase grid-connected Photovoltaic inverter," Industrial Electronics and Applications (ICIEA), 2010 the 5th IEEE Conference, July 2010 , pp. $825-830$

[16] Rujia Men and Xiaoqing Han, "Optimum control and simulation for a grid-connected photovoltaic system," Probabilistic Methods Applied to Power Systems (PMAPS), 2010 IEEE 11th International Conference, July 2010, pp. $431-435$

[17] Azevedo, G.M.S., Cavalcanti, M.C., Oliveira, K.C., Neves, F.A.S. and Lins, Z.D., "Evaluation of maximum power point tracking methods for grid connected photovoltaic systems," Conference on Power Electronics Specialists, 2008. PESC 2008. IEEE , August 2008, pp. $1456-1462$

[18] Kjaer, S.B., Pedersen, J.K. and Blaabjerg, F., "A Review of singlephase grid connected inverters for photovoltaic modules," Industry Applications, IEEE Transactions, vol. 41, September 2005, pp.12921306. 
[19] Jain, S. and Agarwal, V., "A single-stage grid connected inverter topology for solar PV systems with maximum power point tracking," IEEE Transactions on Power Electronics, vol. 22, September 2007, pp. $1928-1940$

[20] Meza, C., Negroni, J.J., Guinjoan, F. and Biel, D., "Inverter Configuration Comparative for Residential PV-grid connected systems,"32nd Annual Conference on IEEE Industrial Electronics, IECON 2006 , April 2007, pp. 4361 - 4366.

[21] A. Nabae, I. Takahashi and H. Akagi, "A new neutral point clamped PWM inverter”, IEEE Trans. Ind. Appl., IA-17 (5) 518-523, 1981.

[22] T. A. Meynard, H. Foch, P. Thomas, J. Couralt, R. Jakob, and M. Naherstaedt, "Multicel converters: Basic consepts and industry application", IEEE Trans. Ind. Electron., 49 (5), 955-964, 2002.

[23] M. F. Escalante, J. C. Vannier, and A. Arzande, "Flying capacitor multilevel inverters and DTC motor drive applications", IEEE Trans. Ind. Elect., 49 (4), 809-815, 2002.

[24] S. S. Fazel, S. Bernet, D. Krug and K. Jalili,"Design and comparison of $4 \mathrm{kV}$ Neutral-pointclamped, flying capacitor and series-connectd $\mathrm{H}$ bridge multilevel converters", IEEE Trans. Ind. Appl., 43(4), 1032 1040, 2007.

[25] J. V. Núñez, "Multilevel Topologies: Can New Inverters Improve Solar Farm Output?" Solar industry journal, 5, 12, 2013.

[26] A. Zabihinejad, P. Viarouge, "Design of Direct Power Controller for a High Power Neutral Point Clamped Converter using Real time Simulator", World Academy of Science, Engineering and Technology, Energy and Power Engineering, 1(1), 187, 2014.

[27] R. Badin, Y. Huang, F. Z. Peng, and H. G. Kim, "Grid interconnected Z-source PV system", Proc. IEEE PESC'07, Orlando, FL, June, pp. 2328-2333, 2007.

[28] F. Z . Peng. "Z-source networks for power conversion". 23rd Ann. IEEE App. Power Elect. Conf. Exp, APEC2008, 24-28 February, Austin, TX, pp. 1258-1265, 2008.

[29] M. Malinowski, K.Gopakumar, Jose Rodriguez, and A. Perez, "A Survey on Cascaded Multilevel Inverters". IEEE Transaction on Industrial Electronics, 57(7), 2010.

[30] P. W. Hammond,." A new approach to enhance power quality for medium voltage AC drives", IEEE Trans.Ind.Appl., 33 ( 1), 202-208, 1997.

[31] T. A. Meynard, M. Fadel, N .Aouda, "Modelling of multilevel converters". IEEE Trans. Industrial Electronics 44(3), 356-364,1997
[32] A. Nordvall "Multilevel Inverter Topology Survey", Master of Science Thesis in Electric Power Engineering, Department of Energy and Environment Division of Electric Power Engineering Chalmers University of technology Göteborg, Sweden, 2011

[33] S. Chakraborty, M. G. Simões, W. E. Kramer "Power electronics for renewable and distributed energy systems", Springer, 2013.

[34] N. S. Cho, "A general circuit topology of multilevel inverter," in Proc. IEEE Power Electron. Specialists Conf., Cambridge, 96-103, 1991.

[35] F. Khoucha, S. Mouna Lagoun, K. Marouani, A. Kheloui and M. Benbouzid." Hybrid Cascaded H-Bridge Multilevel-Inverter Induction Motor-Drive Direct Torque Control for Automotive Applications". IEEE Transactions on Industrial Electronics, Institute of Electrical and Electronics Engineers, 57 (3), 892-899, 2010.

[36] F. Z .Peng. “Z-source inverter. IEEE Trans”. Ind. Appl., 39(2), 504$510,2003$.

[37] Y. Li, J. Anderson, F. Z.Peng, and D.Liu, "Quasi-Z-source inverter for photovoltaic power generation systems". 24th Ann. IEEE Appl. Power Elect. Conf. Exp., APEC 2009, 15-19 February, Washington, DC pp. 918-924, 2009

[38] H. Abu-Rub, A. Iqbal, J.Guzinski, "High performance control of AC drives with Matlab/simulink models" J. Wiley \& S. Ltd IEEE express, 2012 .

[39] H. Abu-Rub, M. Malinowski, K. Alhaddad, power electronics for renewable energy systems, transportation, and industrial applications, John Wiley \& Sons Ltd,A co-publication of IEEE Press, 2014.

[40] J. Huang and K. A. Corzine, "Extended operation of flying capacitor multilevel inverters," IEEE Trans. Power Electron., 21 (1)140- 147, 2006.

[41] S. Sirisukprasert, "Optimized harmonic stepped-waveform for multilevel inverter," M.S. thesis, Dept. Elect. Eng., Virginia Polytechnic Inst. State Univ., Blacksburg, VA, 1999.

[42] B. S.Jin, W. K. Lee, T. J.Kim, D. W.Kang, and D. S. Hyun, "A study on the multi-carrier PWM methods for voltage balancing of flying capacitor in the flying capacitor multilevel inverter". Proc. 31st IEEE Ind. Elect. Conf. IECON, 6-10 November. North Carolina, 721-726, 2005.

[43] S. Mariethoz and , A. Rufer, "Design and control of asymmetrical multilevel inverters," in Proc. Int. Conf. Ind. Electron. Control Instrum., Seville, Spain, pp. 840-845, 2002. 